\title{
Romo1 and the NF-кB pathway are involved in oxidative stress-induced tumor cell invasion
}

\author{
SORA LEE ${ }^{*}$, YOON HEE PARK* , JIN SIL CHUNG and YOUNG DO YOO \\ Laboratory of Molecular Cell Biology, Graduate School of Medicine, \\ Korea University, Seoul 136-705, Republic of Korea
}

Received December 11, 2014; Accepted January 28, 2015

DOI: $10.3892 /$ ijo.2015.2889

\begin{abstract}
Reactive oxygen species (ROS) are important contributors to tumor cell invasion. ROS enhanced by reactive oxygen species modulator 1 (Romol) expression has been reported to increase invasive potential and constitutive activation of nuclear factor- $\kappa \mathrm{B}(\mathrm{NF}-\kappa \mathrm{B})$ in hepatocellular carcinoma (HCC). Therefore, we investigated whether constitutive $\mathrm{NF}-\kappa \mathrm{B}$ activation due to Romol expression is associated with breast cancer tumor cell invasion. In this study, we show that oxidative stress-induced invasion is mediated by Romol expression. The Romol-induced increase of invasive activity was blocked by an inhibitor of $\kappa \mathrm{B}$ kinase (IKK). These results demonstrate that tumor cell invasion in response to oxidative stress is associated with Romol expression and the NF- $\kappa \mathrm{B}$ signaling pathway. Romol is therefore a promising therapeutic target for diseases characterized by $\mathrm{NF}-\kappa \mathrm{B}$ deregulation.
\end{abstract}

\section{Introduction}

Reactive oxygen species (ROS) are produced endogenously through the electron transport pathway in mitochondria as well as various metabolic pathways (1-3). ROS are also generated in response to exogenous stimuli such as chemical stress and irradiation, among others $(2,3)$. They promote tumor progression, including migration, invasiveness and metastasis,

Correspondence to: Professor Young Do Yoo, Laboratory of Molecular Cell Biology, Graduate School of Medicine, Korea University, Seoul 136-705, Republic of Korea

E-mail: ydy1130@korea.ac.kr

*Contributed equally

Abbreviations: $\mathrm{NF}-\kappa \mathrm{B}$, nuclear factor- $\kappa \mathrm{B} ;$ Romo1, reactive oxygen species modulator 1 ; I $\mathrm{B}$, inhibitor of $\kappa \mathrm{B}$; IKK, inhibitor of $\kappa \mathrm{B}$ kinase; ROS, reactive oxygen species; WT, wild-type; MEFs, mouse embryonic fibroblasts; $\mathrm{H}_{2} \mathrm{O}_{2}$, hydrogen peroxide; NAC, $\mathrm{N}$-acetyl-L-cysteine; EMSA, electrophoretic mobility shift assay; TPA, 12-O-tetradecanoylphorbol-13-acetate

Key words: reactive oxygen species, nuclear factor- $\mathrm{\kappa}$, tumor invasion, Romol, oxidative stress by activating a variety of signal cascades (4). ROS induced by 3,5,6-trichloro-2-pyridyloxyacetic acid (TPA) play an important role in cell migration (4). Treatment of mouse mammary epithelial cells with a low dose of hydrogen peroxide $\left(\mathrm{H}_{2} \mathrm{O}_{2}\right)$ resulted in morphological changes and an increase in invasive potential (5). Invasive potential of cells has also been reported to be increased by oxidative stress generated from nicotinamide adenine dinucleotide phosphate (NADPH) oxidase (6).

Nuclear factor- $\kappa \mathrm{B}(\mathrm{NF}-\kappa \mathrm{B})$ is a transcription factor involved in the regulation of development, cell growth, immune response and inflammation (4,7-9). NF- $\kappa \mathrm{B}$ is activated by tumor necrosis factor- $\alpha$ (TNF- $\alpha$ ) stimuli and is associated with tumor cell survival and tumor progression (7). NF- $\kappa \mathrm{B}$ functions as an anti-apoptotic factor, and deregulation of $\mathrm{NF}-\kappa \mathrm{B}$ is often detected in a variety of cancer cell types (10). NF- $\kappa \mathrm{B}$ activity is upregulated in many cancer cells and contributes to tumor cell survival and tumor progression (11-13). NF- $\kappa \mathrm{B}$ is activated by ROS produced by the mitochondrial respiratory chain (14). Exogenous treatment of $\mathrm{H}_{2} \mathrm{O}_{2}$ regulates NF- $\mathrm{NB}$ activation through phosphorylation of inhibitor of $\kappa \mathrm{B}(\mathrm{I} \kappa \mathrm{B}) \alpha(15)$. Inhibitor of $\kappa \mathrm{B}$ kinase (IKK) is also a mediator of ROS-induced $\mathrm{NF}-\kappa \mathrm{B}$ activation (16). IKK is composed of IKK $\alpha$ and $\operatorname{IKK} \beta$, which are catalytic kinases, and IKK $\gamma$, which is a regulatory kinase (7). Treatment of cells with antioxidants such as $\mathrm{N}$-acetyl-L-cysteine (NAC) or pyrrolidine dithiocarbamate (PDTC) inhibits IKK and NF- $\kappa \mathrm{B}$ activation induced by TNF- $\alpha$ or oxidative stress (17). Several studies have demonstrated that constitutive $\mathrm{NF}-\kappa \mathrm{B}$ activation results from sustained activation of upstream mediators such as IKK or an increase in the rate of I $\mathrm{B}$ degradation (18-20). Therefore, cancer cells that show downregulation of $\mathrm{NF}-\kappa \mathrm{B}$ by $\mathrm{I} \kappa \mathrm{B}$ are sensitive to cell death triggered by anti-cancer drugs (21). Suppression of $N F-\kappa B$ activity has also been shown to inhibit tumor cell growth in animal models $(13,22)$.

Reactive oxygen species modulator 1 (Romol) is located in mitochondria, and upregulated Romol expression increases cellular ROS levels $(23,24)$. It was suggested that ROS derived from Romol expression are essential for normal cell growth $(25,26)$. ROS derived from Romol are needed for c-Myc induction for cell cycle entry (27). Increased Romo1 expression induced by c-Myc also plays a role in Skp2-mediated c-Myc degradation via a negative-feedback mechanism. Romol is involved in cell death triggered by serum deprivation, oxidative stress and TNF- $\alpha(28-30)$. Although Romol is 
highly expressed in a variety of cancer cells, the role of Romo1 in cancer progression is unclear (24). Romol triggers DNA damage and its expression is associated with drug-resistance to 5-FU (31,32). Recently, we reported that Romol is highly expressed in hepatocellular carcinoma (HCC) and that overexpression of Romol is associated with tumor cell invasion (24). In a subsequent experiment, Romol stimulated NF- $\mathrm{BB}$ nuclear translocation and DNA-binding activity, and its expression was associated with the constitutive nuclear DNA-binding activity of NF- $\kappa \mathrm{B}$ (33). On the basis of these results, we hypothesized that tumor cell invasion induced by Romol expression is associated with the NF- $\mathrm{NB}$ signaling pathway. To verify this hypothesis, we investigated the correlation between Romo1 expression and $\mathrm{NF}-\kappa \mathrm{B}$ activation in oxidative stress-induced tumor cell invasion.

\section{Materials and methods}

Cell culture. Human breast cancer cell line MDA-MB-231, human hepatocarcinoma cell line Huh-7 and the SV-40 virus-transformed WI-38 (normal lung fibroblasts) cell line WI-38 VA13 were purchased from the Korean Cell Line Bank (Seoul, Korea). Wild-type (WT) mouse embryonic fibroblasts (MEFs) and $\mathrm{IKK} \alpha^{-/-}$and IKK $\beta^{-/-}$MEFs were kindly provided by Dr Inder M. Verma (Salk Institute for Biological Studies, La Jolla, CA, USA). Huh-7, MDA-MB-231, and WT, IKK $\alpha^{-1-}$ and IKK $\beta^{-/-}$MEFs were cultured in Dulbecco's modified Eagle's medium (DMEM) (Gibco/Invitrogen Life Technologies, Grand Island, NY, USA) containing 10\% heat-inactivated fetal bovine serum (FBS) (Life Technologies, Grand Island, NY, USA), $100 \mathrm{U} / \mathrm{ml}$ of penicillin, and $100 \mu \mathrm{g} / \mathrm{ml}$ streptomycin. WI-38 VA13 cells were cultured in Eagle's minimal essential medium (EMEM) (Gibco/Invitrogen Life Technologies) supplemented with $10 \%$ FBS and antibiotics. Cells were grown and maintained at $37^{\circ} \mathrm{C}$ in a humidified incubator with $5 \%$ carbon dioxide.

Chemicals and reagents. $\mathrm{H}_{2} \mathrm{O}_{2}$, NAC, SB203580 (p38 MAPK inhibitor), PD98059 (MKK1/MEK inhibitor), mouse anti-cytosol-specific- $\beta$-actin antibody and anti-Flag (M2) antibody were purchased from Sigma-Aldrich (St. Louis, MO, USA). IKK-16, rabbit polyclonal anti-IKK $\alpha$ antibody, mouse monoclonal anti-IKK $\beta$ (H4) antibody and mouse polyclonal anti-p65 antibody were obtained from Santa Cruz Biotechnology, Inc. (Santa Cruz, CA, USA). Mouse monoclonal antibody against Romo1 was obtained from OriGene Technologies (Rockville, MD, USA). MitoSOX Red was purchased from Molecular Probes (Eugene, OR, USA).

Cell transfection. Romol double-stranded small interfering RNA (siRNA) sequences have been described previously $(27,32)$. Control and Romol siRNA were purchased from Bioneer Corp. (Daejeon, Korea). cDNAs encoding Flag-Romo1 WT were described previously (29). Cells were transfected in 6-well plates or 60-mm dishes using Lipofectamine 2000 (Invitrogen Life Technologies) according to the manufacturer's instructions.

Invasion assay. Invasion assays were performed using polycarbonate nucleopore membranes (Corning, Inc., Corning, NY, USA). Matrigel ( $1 \mathrm{mg} / \mathrm{ml})$ was coated onto the membrane of a Transwell $(6.5 \mathrm{~mm}$ in diameter, $8.0 \mu \mathrm{m}$ pore size). Cells were suspended in serum-free media supplemented with $0.1 \%$ filtered bovine serum albumin (BSA). Cells were seeded on the Matrigel-coated membrane matrix of the Transwell. Cell culture media containing $10 \%$ FBS were added to the lower chamber of the Transwell, and cells were incubated for $24 \mathrm{~h}$ in a $37^{\circ} \mathrm{C}$ incubator. Invasive cells were fixed and stained with Hemacolor ${ }^{\circledR}$ staining solution (Merck KGaA, Darmstadt, Germany). The number of invasive cells was counted using light microscopy.

Immunofluorescence assay. Cells were fixed in $4 \%$ formaldehyde in phosphate-buffered saline (PBS), for $10 \mathrm{~min}$ at room temperature. After fixation, cells were washed with PBS and treated with $0.1 \%$ Triton $\mathrm{X}-100$ in PBS for $5 \mathrm{~min}$ at $4^{\circ} \mathrm{C}$. Cells were then treated with blocking solution (2\% BSA in PBS) for $1 \mathrm{~h}$ at $37^{\circ} \mathrm{C}$. Cells were incubated with primary antibodies in PBS with $1 \%$ BSA and $0.1 \%$ Triton $\mathrm{X}-100$ for $1 \mathrm{~h}$ at $37^{\circ} \mathrm{C}$. After washing in PBS, cells were incubated with appropriate secondary antibodies in PBS with $1 \%$ BSA and $0.1 \%$ Triton X-100 for $30 \mathrm{~min}$ at $37^{\circ} \mathrm{C}$. After washing in PBS, cells were incubated with DAPI in PBS $(1: 10,000)$ for $10 \mathrm{~min}$ at room temperature. Cells were then washed three times in PBS and mounted on glass slides. Confocal analysis was performed using an Olympus LX 50 microscope.

Measurement of ROS generation. Cellular levels of ROS were determined using MitoSOX Red. Cells were stained with $5 \mu \mathrm{M}$ MitoSOX Red at $37^{\circ} \mathrm{C}$ for $20 \mathrm{~min}$. After incubation, cells were washed with PBS, collected in trypsin-EDTA, and suspended in PBS. Fluorescence was measured using a FACScan flow cytometry system (BD Biosciences, Franklin Lakes, NJ, USA).

Electrophoretic mobility shift assay (EMSA). Nuclear proteins were extracted using the NE-PER ${ }^{\circledR}$ Nuclear and Cytoplasmic Extraction Reagents kit (Pierce Biotechnology, Inc. Rockford, IL, USA), according to the manufacturer's instructions. EMSAs for $\mathrm{NF}-\kappa \mathrm{B}$ were performed using the Gelshift $^{\mathrm{TM}}$ Chemiluminescent EMSA kit (Active Motif, Carlsbad, CA, USA) following the manufacturer's instructions. Biotin 3'-end-labeled double-stranded NF- $\kappa$ B oligonucleotide (5'-AGTTGAGGGGACTTTCCCAGGC-3') was purchased from Bioneer Corp. Nuclear protein-NF- $\kappa \mathrm{B}$-labeled oligonucleotide complexes were separated from free $\mathrm{NF}-\kappa \mathrm{B}-$ labeled oligonucleotides by electrophoresis through $6 \%(\mathrm{w} / \mathrm{v})$ polyacrylamide gels. After electrophoretic separation, $\mathrm{NF}-\kappa \mathrm{B}-$ labeled oligonucleotide-protein complexes were transferred to nylon membranes. Membranes were crosslinked, blocked and detected by chemiluminescence.

Western blot analysis. Protein extracts of cells were separated via electrophoresis and transferred to polyvinylidene difluoride (PVDF) membranes (Millipore, Billerica, MA, USA). After blocking with $10 \%$ non-fat dry milk in TBST, membranes were incubated overnight with the appropriate primary antibodies and peroxidase-conjugated secondary antibody. Then, appropriate HRP-conjugated secondary antibodies were added, and protein-antibody complexes were visualized using enhanced chemiluminescence (ECL) reagents (Pierce Biotechnology, Inc.). 
A

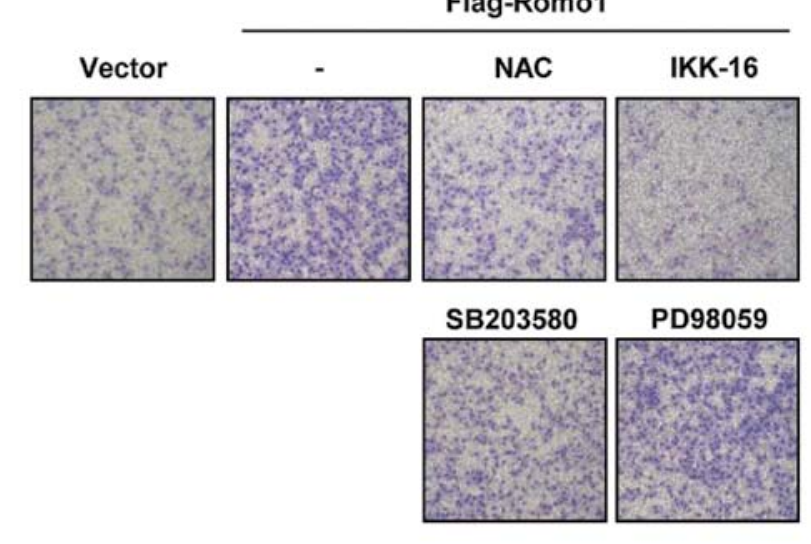

C

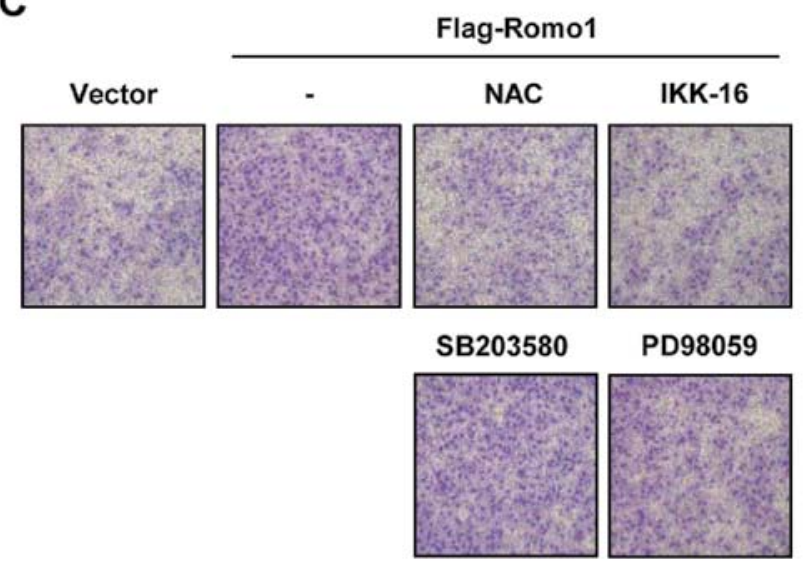

B

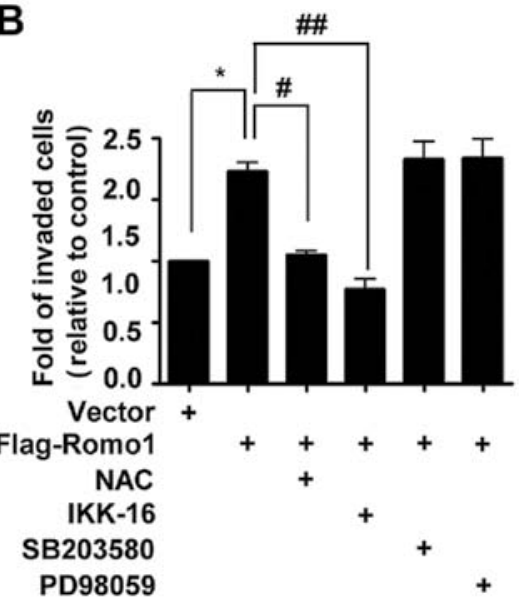

D

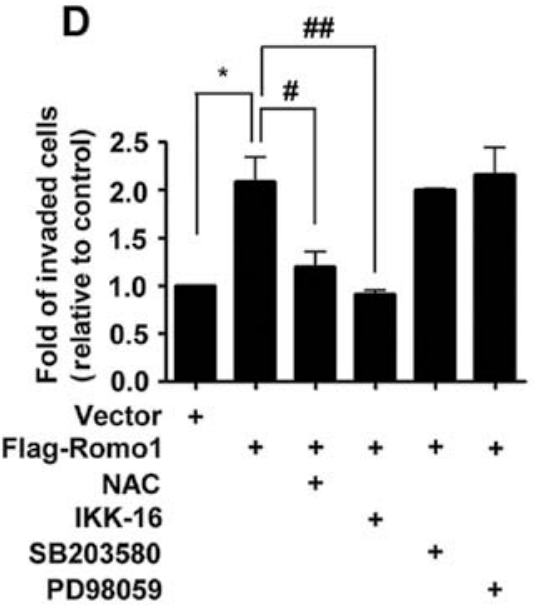

Figure 1. Reactive oxygen species modulator 1 (Romo1)-induced invasion of tumor cells via nuclear factor- $\kappa \mathrm{B}$ (NF- $\kappa \mathrm{B})$ signaling. Flag-tagged Romo1 was transfected into (A) MDA-MB-231 and (C) Huh-7 cells that were then treated with various inhibitors for $14 \mathrm{~h}$. Cell invasion was measured using a Boyden chamber invasion assay. (B and D) Data are presented as the means \pm SEs of at least three independent experiments. ${ }^{*} \mathrm{P}<0.05$ vs. control and ${ }^{\#} \mathrm{P}<0.05$; ${ }^{\# \#} \mathrm{P}<0.01$ vs. Flag-Romo1 by one-way analysis of variance (ANOVA).

RNA preparation, reverse transcription, and polymerase chain reaction (PCR) analysis. Total cellular RNA was prepared using TRIzol reagent (Invitrogen Life Technologies). To synthesize cDNAs, reverse transcription reactions were performed using the following primers: Romol forward, 5'-CTGTCTCAG GATCGGAATGCG-3' and reverse, 5'-CATCGGATGCCCAT CCCAATG-3'; and $\beta$-actin forward, 5'-GAAATCGTGCGT GACATTAAGGAGAAG-3' and reverse, 5'-CTAGAAGCA TTTGCGGTGGACGATGGAGGGGCC-3'. Amplification was performed using a MyCycler Thermal Cycler (Bio-Rad, Hercules, CA, USA). Amplified PCR products were separated on a $1 \%$ agarose gel and visualized using ethidium bromide (EtBr) staining.

Statistical analysis. All experiments were performed independently at least three times. Data are expressed as means \pm SDs, as calculated by GraphPad PRISM version 4.02 for Windows (GraphPad Software, Inc., San Diego, CA, USA). P<0.05 was considered statistically significant.

\section{Results}

Romol-induced invasion involves $N F-\kappa B$ activation. Romo1 expression is known to enhance the invasive activity of tumor cells (24). Romol also contributes to constitutive activation of NF- $\kappa \mathrm{B}$ (33). To determine whether constitutive activation of NF- $\kappa \mathrm{B}$ is involved in Romol-induced invasion, we treated cells with the antioxidant NAC, IKK inhibitor (IKK-16), p38 MAPK inhibitor (SB203580) and MKK1/MEK inhibitor (PD98059). Although Romo1-triggered invasion was not affected by inhibitors of p38 and MEK, it was suppressed by treatment with IKK inhibitor or NAC in MDA-MB-231 cells (Fig. 1A). Similarly, when Huh-7 cells were treated with NAC, IKK inhibitor, p38 inhibitor, or MEK inhibitor, the same result was obtained (Fig. 1C). These results suggest that Romol-induced invasion is mediated by the NF- $\kappa \mathrm{B}$ pathway.

Oxidative stress-induced $N F-\kappa B$ activation and tumor cell invasion requires Romol. Oxidative stress is known to induce cancer cell invasion $(34,35)$. Therefore, we explored whether Romol expression is required for oxidative stress-induced invasion of tumor cells. As shown in Fig. 2A, cell invasion triggered by $\mathrm{H}_{2} \mathrm{O}_{2}$ treatment was blocked by Romo1 knockdown in MDA-MB-231 cells. Similar results were obtained using Huh-7 cells (Fig. 2C), suggesting that Romol is needed for tumor cell invasion in response to oxidative stress. Romol knockdown by Romol siRNA was examined by RT-PCR (data not shown). 
A
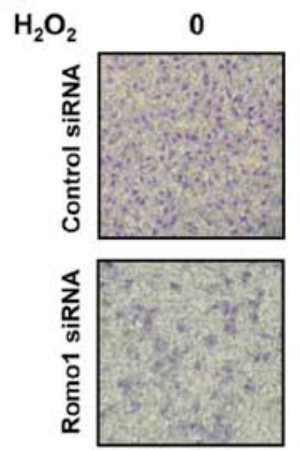

C $\mathrm{H}_{2} \mathrm{O}_{2}$
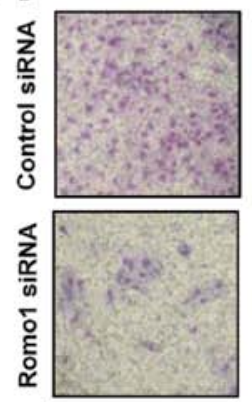

1
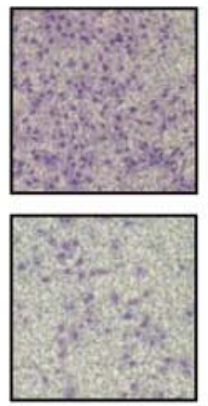

1
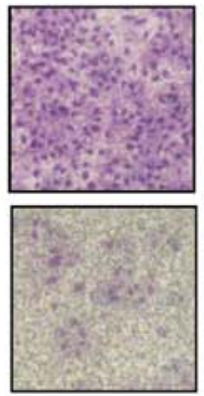

5
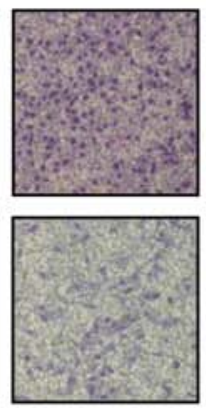

5
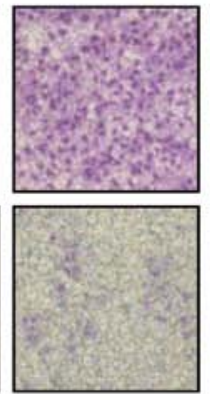

10

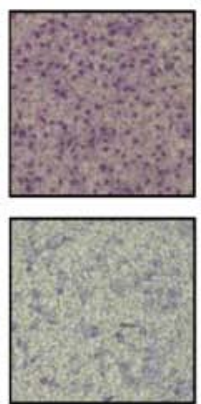

10

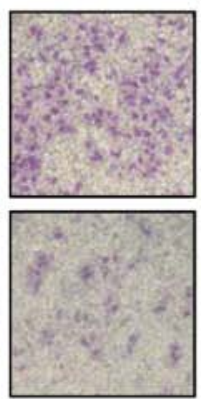

B

$(\mu \mathrm{M})$

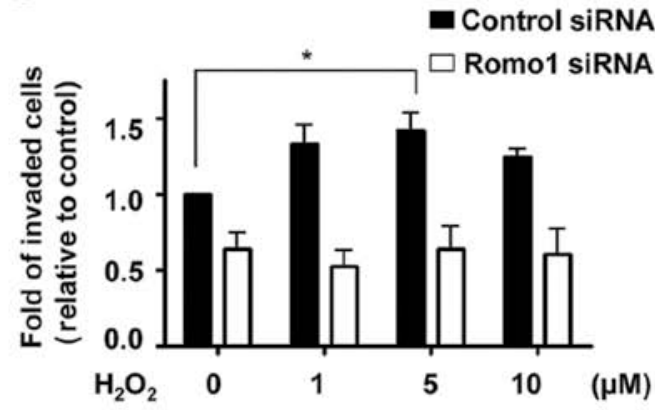

$(\mu \mathrm{M})$

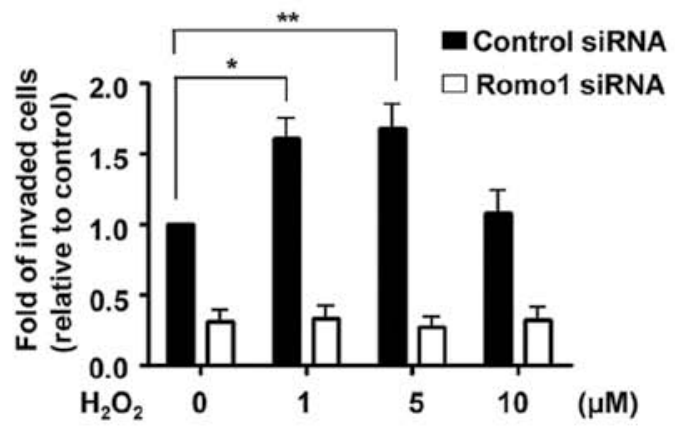

Figure 2. Oxidative stress-induced tumor cell invasion mediated by the reactive oxygen species modulator 1 (Romol). Romol induced tumor cell invasion. After (A) MDA-MB-231 and (C) Huh-7 cells were transfected with Romol small interfering RNA (siRNA) for 24 h, cells were treated with hydrogen peroxide $\left(\mathrm{H}_{2} \mathrm{O}_{2}\right)$ for $1 \mathrm{~h}$. Cell culture media were replaced with fresh media without $\mathrm{H}_{2} \mathrm{O}_{2}$ and cells were further incubated for $23 \mathrm{~h}$ at $37^{\circ} \mathrm{C}$. Cell invasion was examined via the Boyden chamber invasion assay. (B and D) Data are presented as means \pm SEs of at least three independent experiments. ${ }^{*} \mathrm{P}<0.05 ;{ }^{* * *} \mathrm{P}<0.01$ vs. control by one-way analysis of variance (ANOVA).

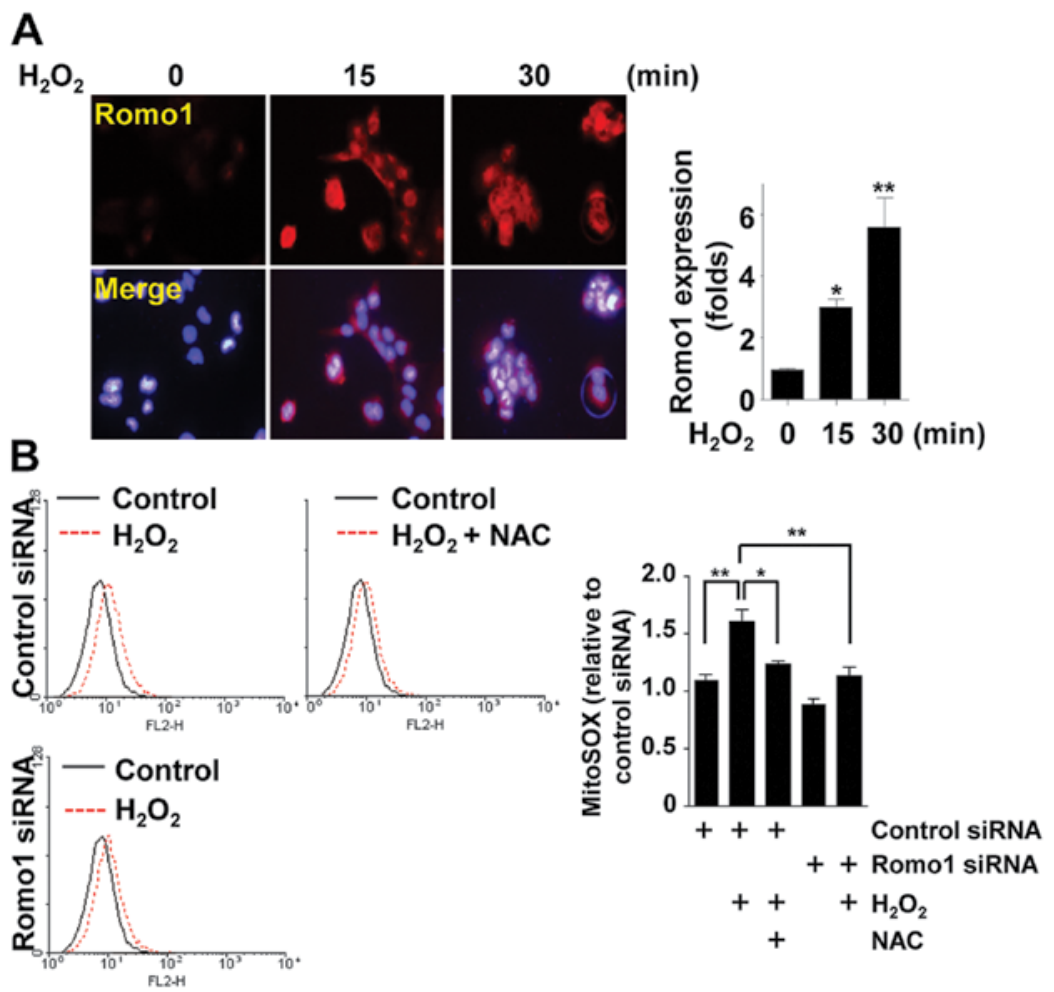

Figure 3. Oxidative stress-induced reactive oxygen species (ROS) production through the reactive oxygen species modulator 1 (Romo1). (A) WI-38 VA13 cells treated with hydrogen peroxide $\left(\mathrm{H}_{2} \mathrm{O}_{2}\right)(500 \mu \mathrm{M})$ for the indicated times were stained with anti-Romol antibody (red) and observed by fluorescence microscopy. Images were quantified using MetaMorph software (Universal Imaging Corp., Bedford Hills, NY, USA). $\mathrm{P}<0.05 ;{ }^{* *} \mathrm{P}<0.01$ vs. untreated control small interfering RNA (siRNA) by two-way analysis of variance (ANOVA). (B) Cells were transfected with Romol siRNA and treated with $\mathrm{H}_{2} \mathrm{O}_{2}$ in the presence or absence of $\mathrm{N}$-acetyl-L-cysteine (NAC) for $1 \mathrm{~h}$. After a change of medium and further culture for $2 \mathrm{~h}$, cells were stained with MitoSOX Red for 30 min and ROS levels were measured by flow cytometry. ${ }^{* *} \mathrm{P}<0.01$ vs. control and ${ }^{*} \mathrm{P}<0.05 ;{ }^{* *} \mathrm{P}<0.01$ vs. control siRNA with treatment of $\mathrm{H}_{2} \mathrm{O}_{2}$ by two-way analysis of variance (ANOVA). 
A

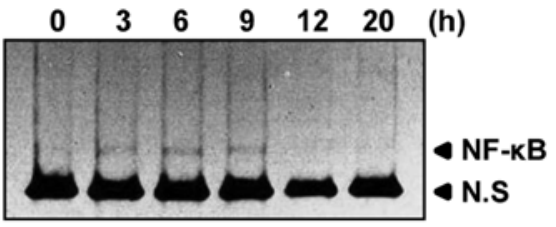

B

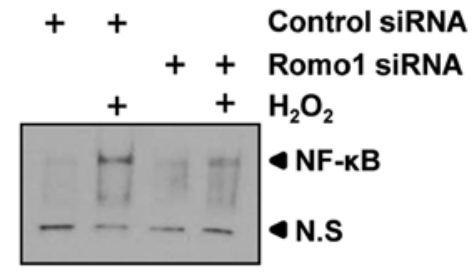

C

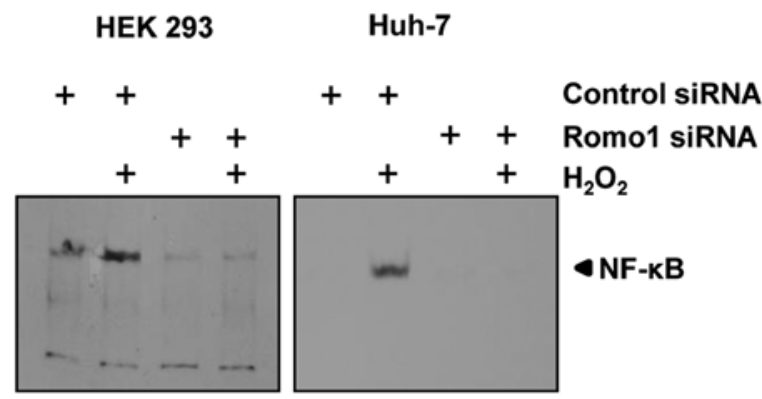

Figure 4. Oxidative stress-induced nuclear factor- $\mathrm{\kappa B}(\mathrm{NF}-\kappa \mathrm{B})$ activation of tumor cells through the reactive oxygen species modulator 1 (Romo1). (A) Electrophoretic mobility shift assay (EMSA) was performed using nuclear extracts isolated at the indicated times from WI-38 VA13 cells treated with hydrogen peroxide $\left(\mathrm{H}_{2} \mathrm{O}_{2}\right)$ for $3 \mathrm{~h}$. (B) EMSA was performed using WI-38 VA13 cells transfected with Romol small interfering RNA (siRNA) and treated with $\mathrm{H}_{2} \mathrm{O}_{2}$. (C) EMSA was performed using HEK 293 cells and Huh-7 cells transfected with Romol siRNA and treated with $\mathrm{H}_{2} \mathrm{O}_{2}$.

$\mathrm{NF}-\kappa \mathrm{B}$ is a major transcription factor involved in sensing $\mathrm{H}_{2} \mathrm{O}_{2}$-mediated oxidative stress $(14,36)$. To evaluate the role of Romol in chronic oxidative stress-induced $\mathrm{NF}-\kappa \mathrm{B}$ activation, we first confirmed the pathway of activation, that is, $\mathrm{H}_{2} \mathrm{O}_{2}$-Romol-ROS-NF- $\kappa \mathrm{B}$. Following treatment of WI-38 VA13 cells with $\mathrm{H}_{2} \mathrm{O}_{2}$, Romol expression was observed to increase on fluorescence microscopy (Fig. 3A). Production of ROS following $\mathrm{H}_{2} \mathrm{O}_{2}$ treatment was measured by staining cells with MitoSOX Red (an indicator of mitochondrial superoxide). Flow cytometric analysis showed that Romol depletion and NAC treatment partially inhibited $\mathrm{H}_{2} \mathrm{O}_{2}$-mediated ROS production (Fig. 3B). To clarify the role of Romol in $\mathrm{H}_{2} \mathrm{O}_{2}$-induced NF- $\kappa \mathrm{B}$ activation, WI-38 VA13 cells were treated with $\mathrm{H}_{2} \mathrm{O}_{2}$ and an EMSA was performed. As shown in Fig. 4A, the DNA-binding activity of $\mathrm{NF}-\kappa \mathrm{B}$ increased following $\mathrm{H}_{2} \mathrm{O}_{2}$ treatment, and binding activity was sustained for up to $9 \mathrm{~h} . \mathrm{H}_{2} \mathrm{O}_{2}$-mediated $\mathrm{NF}-\kappa \mathrm{B}$ activation was suppressed by Romol knockdown (Fig. 4B). This finding was also confirmed in HEK 293 and Huh-7 cells (Fig. 4C). These results demonstrated that oxidative stress can induce $\mathrm{NF}-\kappa \mathrm{B}$ activation through Romol expression.

Romol-induced NF- $\kappa$ B activation and invasion of cells involves $I K K$. Catalytic subunits of the IKK complex, namely IKK $\alpha$ and IKK $\beta$, are principally involved in $\mathrm{I} \kappa \mathrm{B} \alpha$ phosphorylation (8). To determine whether Romol regulates NF- $\kappa \mathrm{B}$ activation via the IKK complex, we used IKK $\alpha$ - or IKK $\beta$-deficient cells $\left(\mathrm{IKK} \alpha^{-/-}\right.$and IKK $\beta^{-/-}$) derived from primary MEFs. As shown in Fig. 5A, Romol expression triggered the nuclear translocation of p65 in WT MEFs. However, the nuclear translocation of p65 was not detectable in IKK $\alpha^{-/}$cells. In contrast, p65 was partially detectable in the nucleus of IKK $\beta^{-/-}$cells. This result was confirmed by EMSA, and the same result was observed, as shown in Fig. 5B. Expression of IKK $\alpha$ and IKK $\beta$ was examined by western blot analysis (Fig. 5C). Together, these results demonstrate that IKK $\alpha$ is an essential mediator of NF- $\kappa \mathrm{B}$ activation induced by Romol expression.

To further investigate the importance of IKK $\alpha$ in Romo1induced invasion, Romol was expressed in WT MEF, $\mathrm{IKK}^{-/-}$and IKK $\beta^{-/-} \mathrm{MEF}$ cells, and Romol-induced invasion was assessed. As expected, IKK $\alpha^{-/-}$and IKK $\beta^{-/-}$MEF cells were less invasive than WT MEF cells. Romol-induced invasion was suppressed in IKK $\alpha^{-/}$cells and was partially suppressed in IKK $\beta^{-/-}$cells (Fig. 6).

\section{Discussion}

Oxidative stress is a contributor to cancer cell invasion $(4,37)$. ROS are closely associated with the NF- $\mathrm{B}$ pathway and, as a result, stimulate the MMPs involved in invasion and metastasis (4). A variety of cellular stresses, including carcinogens, cigarette smoke and TPA, may induce $\mathrm{NF}-\kappa \mathrm{B}$ expression as well as the expression of pro-inflammatory genes $(10,38)$. Romol expression is similarly induced by a variety of stresses such as TPA, $\mathrm{H}_{2} \mathrm{O}_{2}$ and chemotherapeutic agents $(24,29,32)$. This implies that stress-induced $\mathrm{NF}-\kappa \mathrm{B}$ activation could be mediated by Romol expression. In the present study, $\mathrm{H}_{2} \mathrm{O}_{2}$-induced $\mathrm{NF}-\kappa \mathrm{B}$ activation was associated 

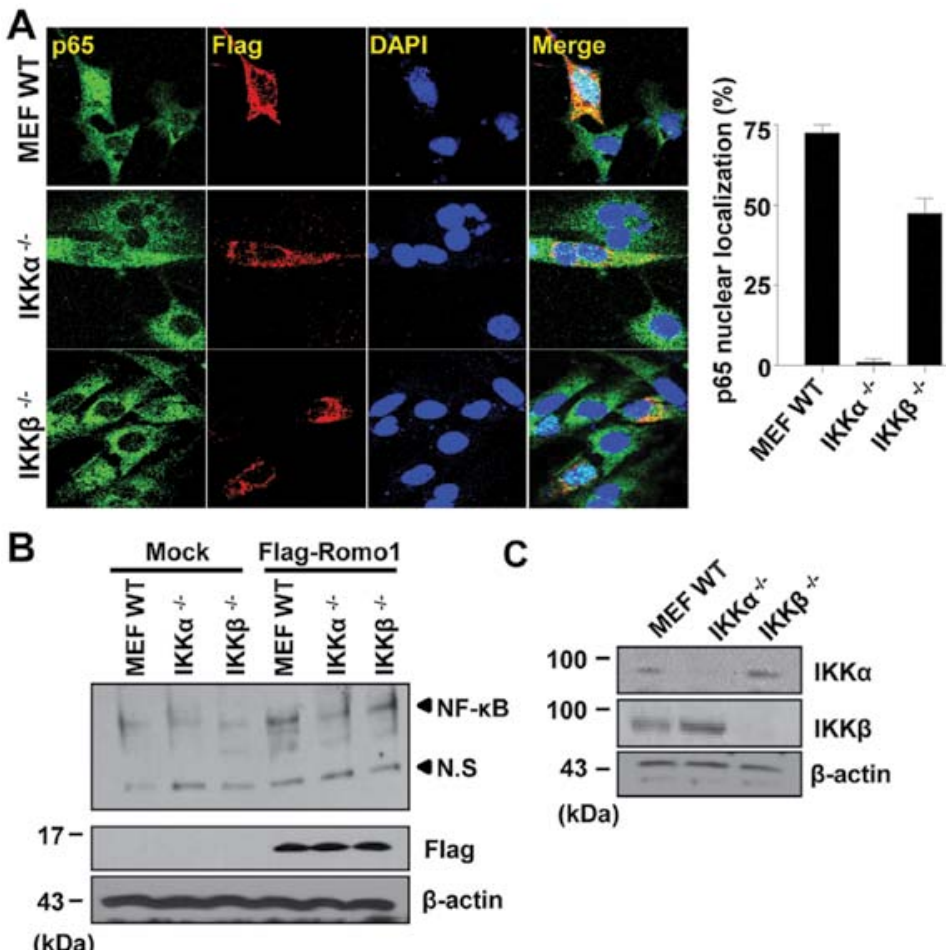

(kDa)

(kDa)

Figure 5. The reactive oxygen species modulator 1 (Romo1)-induced nuclear factor- $\kappa \mathrm{B}(\mathrm{NF}-\kappa \mathrm{B})$ activation through the inhibitor of $\kappa \mathrm{B}$ kinase (IKK). (A) Wild-type (WT), IKK $\alpha^{-/-}$and IKK $\beta^{-/}$mouse embryonic fibroblast (MEF) cells were stained with anti-p65 antibody (green) or anti-Flag antibody (red) after Flag-tagged Romol transfection, and subcellular localization of p65 was then observed by confocal microscopy, with 100 cells monitored per experiment. Representative results from three independent experiments are shown. (B) Nuclear extracts were isolated from WT MEF, IKK $\alpha^{-/}$and IKK $\beta^{-/}$cells after Flag-tagged Romol transfection, and the DNA-binding activity of NF- $\mathrm{kB}$ was determined by electrophoretic mobility shift assay (EMSA). (C) Expression of $\mathrm{IKK} \alpha$ and IKK $\beta$ was evaluated by western blot analysis.
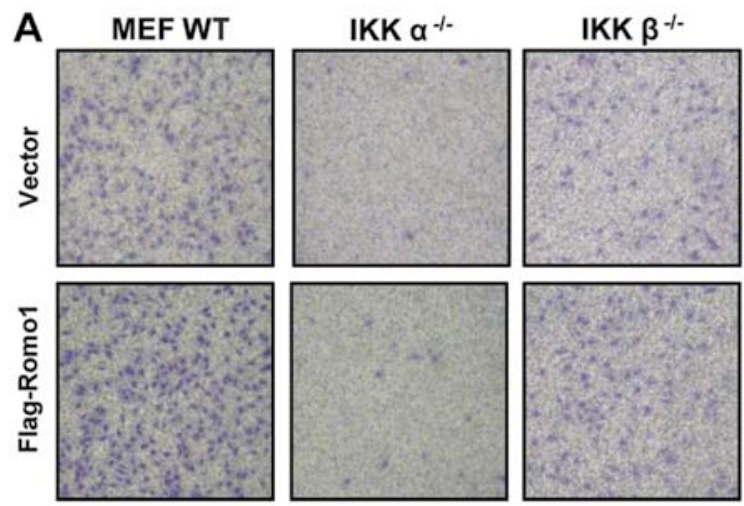

B

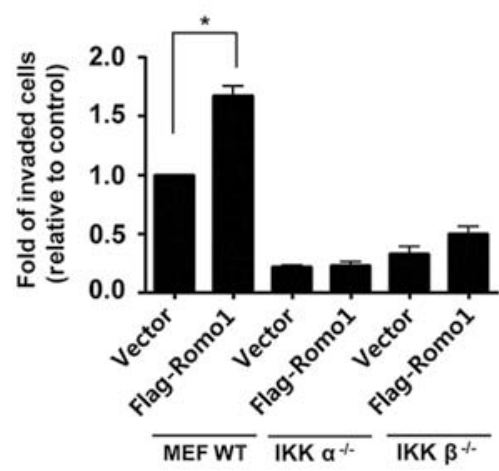

Figure 6. Reactive oxygen species modulator 1 (Romo1)-induced cell invasion through the inhibitor of $\kappa \mathrm{B}$ kinase (IKK). (A) After Romol was expressed in wild-type (WT), IKK $\alpha^{-/}$and IKK $\beta^{-/}$mouse embryonic fibroblast (MEF) cells for $14 \mathrm{~h}$, a cell invasion assay was performed using a Boyden chamber. (B) Data are presented as means \pm SEs of at least three independent experiments. " $\mathrm{P}<0.05$ vs. control by one-way analysis of variance (ANOVA).

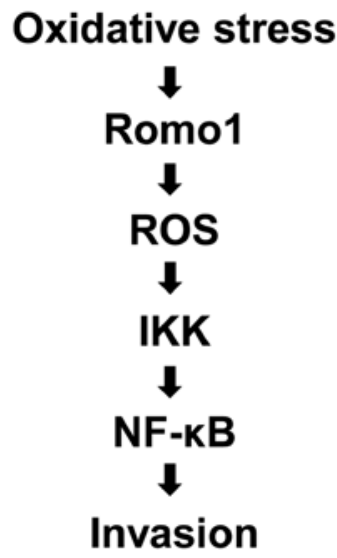

Figure 7. Diagram showing the putative role of the reactive oxygen species modulator 1 (Romol) and the nuclear factor- $\mathrm{\kappa B}(\mathrm{NF}-\mathrm{\kappa B})$ pathway in oxidative stress-induced tumor cell invasion.

with Romo1 expression (Fig. 4). In a previous report, we demonstrated that increased NF- $\mathrm{\kappa B}$ activity was decreased by Romol knockdown and that Romol overexpression induced translocation of NF- $\mathrm{KB}$ into the nucleus and its binding to DNA (33). These results indicated that an increase in activity of NF- $\mathrm{KB}$ in tumor cells is closely related to Romol expression triggered by oxidative stress. Because aberrant NF- $\kappa \mathrm{B}$ activation is associated with a variety of inflammatory diseases, drug-development efforts have targeted components of NF- $\kappa \mathrm{B}$ signaling such as I $\mathrm{B} \alpha \alpha$ degradation, IKK activity and NF- $\mathrm{KB}$ binding to DNA $(11,39)$. Our results suggest that 
Romol is another potential therapeutic target for diseases involving NF- $\kappa \mathrm{B}$ deregulation.

$\mathrm{NF}-\kappa \mathrm{B}$ plays a key role in tumor cell invasion (20), therefore we investigated whether oxidative stress-induced Romol expression is associated with tumor cell invasion via $\mathrm{NF}-\kappa \mathrm{B}$ signaling. In previous studies, we showed that TPA-induced invasion of HCC is mediated by Romol expression and that Romol expression is closely related to constitutive activation of NF- $\kappa \mathrm{B}(24,33)$. Increased NF- $\kappa \mathrm{B}$ activity has been reported in many types of cancer cells, and this deregulated $N F-\kappa B$ activity is responsible for cell proliferation, progression and resistance to apoptosis of various tumor cells $(11,12,40)$. In the present study, we showed that Romo1-triggered cell invasion was suppressed by NF- $\mathrm{NB}$ inhibition. These results demonstrate that Romol-induced tumor cell invasion is mediated by $N F-\kappa B$ activation. Constitutive $N F-\kappa B$ activation is also due to Romo1 expression (33). A variety of stresses induce $\mathrm{NF}-\kappa \mathrm{B}$ activation $(17,41)$. Romol expression is also enhanced by various stresses in tumor cells (24). Therefore, we suggest that various types of stress, particularly oxidative stress, promote tumor cell invasion through Romol expression and constitutive NF- $\kappa \mathrm{B}$ activation.

It has been reported that deregulated $\mathrm{NF}-\kappa \mathrm{B}$ activation is due to constitutive activation of an upstream mediator, such as IKK, or an increase in the rate of $\mathrm{I} \kappa \mathrm{B}$ degradation $(18,20)$. IKK $\beta$ participates in most canonical signaling pathways leading to $\mathrm{NF}-\kappa \mathrm{B}$ activation. However, IKK $\alpha$ may also participate in ROS-induced NF- $\kappa \mathrm{B}$ activation in TNF- $\alpha$-treated cells (17). In some cells, IKK $\alpha$ plays a prominent role in regulating constitutive $\mathrm{NF}-\kappa \mathrm{B}$ activity (19). We demonstrated in the current study that tumor cell invasion induced by Romol overexpression was blocked by NAC and IKK-16 (Fig. 1). This result implied that tumor cell invasion induced by Romo1 expression was mediated by IKK activity. Therefore, we investigated the involvement of IKK by performing experiments in IKK $\alpha$ - or IKK $\beta$-deficient cells. We found that while both IKK $\alpha$ and IKK $\beta$ contributed to Romol-induced NF- $\kappa \mathrm{B}$ activation, IKK $\alpha$ was the major mediator. The putative role of Romol in oxidative stress-induced tumor cell invasion via the NF- $\kappa \mathrm{B}$ pathway is summarized in Fig. 7. Based on these results and those of previous studies, we suggest that Romol is an important upstream mediator of constitutive activation of the NF- $\mathrm{KB}$ pathway responsible for tumor cell invasion.

\section{Acknowledgements}

This study was supported by the National Research Foundation of Korea (NRF) grant funded by the Korean government (NRF-2012R1A2A2A01045800 and NRF2013R1A1A2063171) and by a grant from the National R\&D Program for Cancer Control, Ministry for Health, Welfare and Family Affairs, Republic of Korea (1020180).

\section{References}

1. Finkel T: Oxygen radicals and signaling. Curr Opin Cell Biol 10: 248-253, 1998

2. Dröge W: Free radicals in the physiological control of cell function. Physiol Rev 82: 47-95, 2002.

3. Bae YS, Oh H, Rhee SG and Yoo YD: Regulation of reactive oxygen species generation in cell signaling. Mol Cells 32: 491-509, 2011.
4. Wu WS: The signaling mechanism of ROS in tumor progression. Cancer Metastasis Rev 25: 695-705, 2006.

5. Mori K, Shibanuma M and Nose K: Invasive potential induced under long-term oxidative stress in mammary epithelial cells. Cancer Res 64: 7464-7472, 2004.

6. Kumar B, Koul S, Khandrika L, Meacham RB and Koul HK: Oxidative stress is inherent in prostate cancer cells and is required for aggressive phenotype. Cancer Res 68: 1777-1785, 2008.

7. Baldwin AS Jr: The NF-kappa B and I kappa B proteins: new discoveries and insights. Annu Rev Immunol 14: 649-683, 1996.

8. Karin M: How NF-kappaB is activated: the role of the IkappaB kinase (IKK) complex. Oncogene 18: 6867-6874, 1999.

9. Ghosh S and Hayden MS: New regulators of NF-kappaB in inflammation. Nat Rev Immunol 8: 837-848, 2008.

10. Sovak MA, Bellas RE, Kim DW, Zanieski GJ, Rogers AE, Traish AM and Sonenshein GE: Aberrant nuclear factor$\mathrm{kappaB} / \mathrm{Rel}$ expression and the pathogenesis of breast cancer. J Clin Invest 100: 2952-2960, 1997.

11. Kim HJ, Hawke N and Baldwin AS: NF-kappaB and IKK as therapeutic targets in cancer. Cell Death Differ 13: 738-747, 2006.

12. Sasaki N, Morisaki T, Hashizume K, et al: Nuclear factor-kappaB p65 (RelA) transcription factor is constitutively activated in human gastric carcinoma tissue. Clin Cancer Res 7: 4136-4142, 2001.

13. Bargou RC, Emmerich F, Krappmann D, et al: Constitutive nuclear factor-kappaB-RelA activation is required for proliferation and survival of Hodgkin's disease tumor cells. J Clin Invest 100: 2961-2969, 1997.

14. Josse C, Legrand-Poels S, Piret B, Sluse F and Piette J: Impairment of the mitochondrial electron chain transport prevents NF-kappa B activation by hydrogen peroxide. Free Radic Biol Med 25: 104-112, 1998.

15. Morgan MJ and Liu ZG: Crosstalk of reactive oxygen species and NF- $\kappa \mathrm{B}$ signaling. Cell Res 21: 103-115, 2011.

16. Jaspers I, Zhang W, Fraser A, Samet JM and Reed W: Hydrogen peroxide has opposing effects on IKK activity and IkappaBalpha breakdown in airway epithelial cells. Am J Respir Cell Mol Biol 24: 769-777, 2001.

17. Oka S, Kamata H, Kamata K, Yagisawa H and Hirata H: N-acetylcysteine suppresses TNF-induced NF-kappaB activation through inhibition of IkappaB kinases. FEBS Lett 472: 196-202, 2000.

18. Gasparian AV, Yao YJ, Kowalczyk D, Lyakh LA, Karseladze A, Slaga TJ and Budunova IV: The role of IKK in constitutive activation of NF-kappaB transcription factor in prostate carcinoma cells. J Cell Sci 115: 141-151, 2002.

19. Wilson W III and Baldwin AS: Maintenance of constitutive IkappaB kinase activity by glycogen synthase kinase-3alpha/beta in pancreatic cancer. Cancer Res 68: 8156-8163, 2008.

20. Miyamoto S, Chiao PJ and Verma IM: Enhanced I kappa B alpha degradation is responsible for constitutive NF-kappa B activity in mature murine B-cell lines. Mol Cell Biol 14: 3276-3282, 1994.

21. Wang CY, Mayo MW and Baldwin AS Jr: TNF- and cancer therapy-induced apoptosis: potentiation by inhibition of NF-kappaB. Science 274: 784-787, 1996

22. Visconti R, Cerutti J, Battista S, et al: Expression of the neoplastic phenotype by human thyroid carcinoma cell lines requires NFkappaB p65 protein expression. Oncogene 15: 1987-1994, 1997.

23. Chung YM, Kim JS and Yoo YD: A novel protein, Romo1, induces ROS production in the mitochondria. Biochem Biophys Res Commun 347: 649-655, 2006.

24. Chung JS, Park S, Park SH, et al: Overexpression of Romo1 promotes production of reactive oxygen species and invasiveness of hepatic tumor cells. Gastroenterology 143: 1084-1094.e7, 2012.

25. Na AR, Chung YM, Lee SB, Park SH, Lee MS and Yoo YD: A critical role for Romol-derived ROS in cell proliferation. Biochem Biophys Res Commun 369: 672-678, 2008.

26. Chung JS, Lee SB, Park SH, Kang ST, Na AR, Chang TS, $\mathrm{Kim} \mathrm{HJ}$ and Yoo YD: Mitochondrial reactive oxygen species originating from Romol exert an important role in normal cell cycle progression by regulating p27(Kip1) expression. Free Radic Res 43: 729-737, 2009.

27. Lee SB, Kim JJ, Chung JS, Lee MS, Lee KH, Kim BS and Do Yoo Y: Romol is a negative-feedback regulator of Myc. J Cell Sci 124: 1911-1924, 2011.

28. Shin JA, Chung JS, Cho SH, Kim HJ and Yoo YD: Romo1 expression contributes to oxidative stress-induced death of lung epithelial cells. Biochem Biophys Res Commun 439: 315-320, 2013. 
29. Kim JJ, Lee SB, Park JK and Yoo YD: TNF-alpha-induced ROS production triggering apoptosis is directly linked to Romol and Bcl-X(L). Cell Death Differ 17: 1420-1434, 2010.

30. Lee SB, Kim JJ, Kim TW, Kim BS, Lee MS and Yoo YD: Serum deprivation-induced reactive oxygen species production is mediated by Romol. Apoptosis 15: 204-218, 2010.

31. Chung YM, Lee SB, Kim HJ, Park SH, Kim JJ, Chung JS and Yoo YD: Replicative senescence induced by Romol-derived reactive oxygen species. J Biol Chem 283: 33763-33771, 2008

32. Hwang IT, Chung YM, Kim JJ, Chung JS, Kim BS, Kim HJ, Kim JS and Yoo YD: Drug resistance to 5-FU linked to reactive oxygen species modulator 1. Biochem Biophys Res Commun 359: 304-310, 2007.

33. Chung JS, Lee S and Yoo YD: Constitutive NF- $\kappa B$ activation and tumor-growth promotion by Romol-mediated reactive oxygen species production. Biochem Biophys Res Commun 450: 1656-1661, 2014

34. Ho BY, Wu YM, Chang KJ and Pan TM: Dimerumic acid inhibits SW620 cell invasion by attenuating $\mathrm{H}_{2} \mathrm{O}_{2}$-mediated MMP-7 expression via JNK/C-Jun and ERK/C-Fos activation in an AP-1-dependent manner. Int J Biol Sci 7: 869-880, 2011.

35. Liu Z, Li S, Cai Y, Wang A, He Q, Zheng C, Zhao T, Ding X and Zhou X: Manganese superoxide dismutase induces migration and invasion of tongue squamous cell carcinoma via $\mathrm{H}_{2} \mathrm{O}_{2}$-dependent Snail signaling. Free Radic Biol Med 53: 44-50, 2012
36. Schreck R, Rieber P and Baeuerle PA: Reactive oxygen intermediates as apparently widely used messengers in the activation of the NF-kappa B transcription factor and HIV-1. EMBO J 10: 2247-2258, 1991.

37. Nonaka Y, Iwagaki H, Kimura T, Fuchimoto S and Orita K: Effect of reactive oxygen intermediates on the in vitro invasive capacity of tumor cells and liver metastasis in mice. Int $\mathrm{J}$ Cancer 54: 983-986, 1993.

38. Staal FJ, Roederer M, Herzenberg LA and Herzenberg LA: Intracellular thiols regulate activation of nuclear factor kappa B and transcription of human immunodeficiency virus. Proc Natl Acad Sci USA 87: 9943-9947, 1990.

39. Ahn KS and Aggarwal BB: Transcription factor NF-kappaB: a sensor for smoke and stress signals. Ann N Y Acad Sci 1056: 218-233, 2005.

40. Rayet B and Gélinas C: Aberrant rel/nfkb genes and activity in human cancer. Oncogene 18: 6938-6947, 1999.

41. Kamata H, Manabe T, Oka S, Kamata K and Hirata H: Hydrogen peroxide activates IkappaB kinases through phosphorylation of serine residues in the activation loops. FEBS Lett 519: 231-237, 2002. 